\title{
Multivariate analysis of patients with blunt trauma and possible factors affecting mortality
}

\author{
Adnan Özpek, M.D., ${ }^{1}$ Metin Yücel, M.D., ${ }^{1}$ İbrahim Atak, M.D., ${ }^{1}$ \\ Gürhan Baş, M.D., ${ }^{1}$ Orhan Alimoğlu, M.D. ${ }^{2}$ \\ ${ }^{1}$ Department of General Surgery, Umraniye Training and Research Hospital, Istanbul \\ ${ }^{2}$ Department of General Surgery, Medeniyet University Faculty of Medicine, Istanbul
}

\begin{abstract}
BACKGROUND: This study aimed to investigate the signs and prognosis of the patients hospitalized due to blunt trauma injuries and identify possible factors that affect mortality.

METHODS: Between January 2009 and January 20I3, a total of 237 patients admitted with blunt trauma injury were retrospectively analyzed. The age and gender of the patients, type of the trauma, injury site, Injury Severity Scores (ISS), Revised Trauma Scores (RTS), Focused Assessment with Sonography in Trauma (FAST) results, hemodynamic status, need for transfusion, treatment modalities, treatment outcomes, and mortality rates were recorded.
\end{abstract}

RESULTS: Of the patients, I 87 (78.9\%) were male, 50 (2I.1\%) were female and mean age was $36.9 \pm 16.9$ years (3-8I years). Of the patients, I3I (55.3\%) suffered thoracic injuries, II 0 (46.6\%) abdominal injuries, 96 (40.5\%) pelvic and limb injuries, 34 (I4.3\%) head and neck injuries, 26 (1 I\%) maxillofacial injuries, and 24 (10.1\%) skin and subcutaneous tissue injuries. Forty-five patients (I9\%), including 33 patients with hemodynamic instability and 12 patients with peritonitis-related signs, were operated on. Mortality was seen in 26 patients (1 I\%), including 10 (38.5\%) with unstable pelvic fractures. Mortality rates; in patients with packing performed was 75\%, in patients without any need for packing was $33.3 \%$, in patients with hemodynamic instablity was $60.6 \%$, in hemodynamically stable patients was $8.3 \%$ and in FAST $(+)$ patients was $20.5 \%$, in FAST $(-)$ patients was $3.4 \%(p<0.05)$.

CONCLUSION: Blunt trauma often presents with multi-trauma involving more than one anatomical structure of the body. Thoracic, abdominal, and pelvic injuries usually accompany blunt trauma. The majority of abdominal solid organ injuries are followed nonoperatively. Our study results show that ISS, RTS, FAST result, hemodynamic unstability, packing requirment, and need for transfusion are statistically invaluable in identifying the mortality risk.

Key words: Blunt trauma; Injury Severity Score; mortality; multi-trauma; Revised Trauma Score; transfusion.

\section{INTRODUCTION}

Trauma-related mortality is one of the leading causes of global death, accounting for $9 \%$ of all deaths in all age groups. It is also the major cause of death in individuals aged 5 to 49

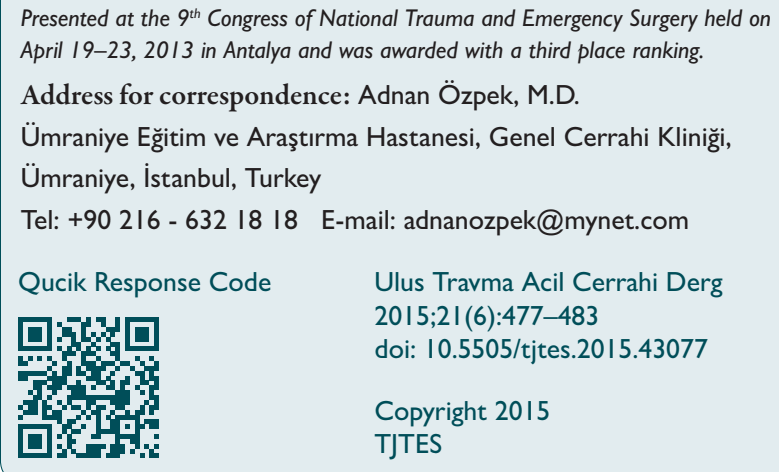

years. ${ }^{[1]}$ Most trauma-related injuries are blunt injuries. ${ }^{[1]}$ Such injuries can be caused primarily by traffic accidents, falls from height, or assaults. ${ }^{[1]}$ Blunt trauma injuries, which often present with multi-trauma involving more than one anatomical structure of the body, are the main causes of emergency admissions. ${ }^{[2,3]}$ Therefore, management and follow-up of these injuries require a multidisciplinary approach. The mortality and morbidity rate of blunt trauma injuries are higher than penetrating trauma injuries. ${ }^{[4]}$ Based on the trimodal distribution of trauma deaths proposed by Trunkey in 1983, 50\% of deaths occur immediately or within seconds of injury, $30 \%$ occur within a few hours, and $20 \%$ occur within a few weeks. ${ }^{[5]}$ As a result, pre-hospital services that prevent trauma injuries are of utmost importance. In addition, emergency physicians and the equipment of the facility play a critical role in reducing the mortality rate that occurs within a few hours. The mortality rate can be reduced in fully equipped emergency trauma centers where a multidisciplinary team including phy- 
sicians and other healthcare staff trained on the management of trauma injuries is available. ${ }^{[6,7]}$ In Turkey, general surgeons are still mostly faced with patients with multi-trauma injuries in State Hospitals, University Hospitals, and Training and Research Hospitals, followed by the request for consultation. These patients may be referred to the related department for additional therapies when their clinical status is stable.

The current study aimed to investigate the signs and prognosis of the patients hospitalized due to blunt trauma injuries and identify possible factors that affect mortality.

\section{MATERIALS AND METHODS}

This retrospective study included a prospective database of a total of 237 patients who were admitted to the Emergency Department with blunt trauma injury and hospitalized in the General Surgery Inpatient Unit between January 2009 and January 20I3. All patients were resuscitated on admission in accordance with the Advanced Trauma Life Support (ATLS) protocol. According to this protocol, the patients were monitorised in the Emergency Room (ER) as yellow or red area and were resuscitated with ABCDEF approach. Patients were accepted as hemodynamically unstable with an arterial systolic blood pressure of less than $90 \mathrm{mmHg}$, after they were ressucitated with cristalloids and blood products, via at least 2 intravenous lines with $2000 \mathrm{cc}$ (for children $20 \mathrm{cc} / \mathrm{kg}$ ) in 15 minutes. Similarly, if systolic blood pressure improved after ressucitation, but could not be stabilised, then, they were accepted as unsustainable hemodynamic stability. The patients with hemodynamic instability or unsustainable stability based on the ATLS criteria underwent Focused Assessment with Sonography in Trauma (FAST). In patients with free abdominal fluid in FAST, emergency laparotomy was performed. Hemodynamically stable patients were admitted to the clinic after FAST, and computerized tomography (CT) and/or other imaging modalities and consultations were carried out. Some of these patients were operated on after developing peritonitis findings or hemodynamic instability.

When a thoracotomy was indicated, a thoracic surgeon was consultated for the operation. Most of the tube thoracostomies were performed by general surgeons, some by thoracic surgeons. In unstable pelvic fractures, external fixations were done by orthopedic surgeons, and pelvic packing, if required, was performed by general surgeons. All management and follow-up of the patients were conducted by general surgeons in the Intensive Care Unit (ICU) and/or general surgery inpatient unit.

Abbreviated Injury Scale (AIS) was used to identify the injury site and grade injuries. Injury Severity Scores (ISS) and Revised Trauma Scores (RTS) were estimated. According to vital signs, the patients were followed in the ICU or general surgery inpatient unit. The age and gender of the patients, type of the trauma, injury site, ISS $(0-75)$ and RTS $(0-7,84)$ levels, FAST results, hemodynamic status, need for transfusion, treatment modalities, treatment outcomes, and mortality rates were analyzed.

Statistical analysis was performed using the Number Cruncher Statistical System (NCSS; NCSS LLC, Utah, USA) 2007 update and Power Analysis and Sample Sizes (PASS; NCSS LLC, Utah, USA) software. Chi-square and Fisher's exact test (NCSS 2007 Kaysville, Utah, USA) were performed to analyze categorical variables. $\mathrm{p}$ value of $<0.05$ was considered statistically significant.

\section{RESULTS}

Of the two hundred and thirty-seven patients, I 87 (78.9\%) were male and 50 (21.1\%) were female. Mean age was $36.9 \pm 16.9$ years (range, $3-81$ years). The main cause of blunttrauma injury was in-vehicle traffic accident in sixty-six patients $(27.8 \%)$, fall from a height in sixty-four patients $(27 \%)$, traffic accident involving a pedestrian in fifty-five patients (23.2\%), motorbike accident in twenty-six patients ( $11 \%$ ), crush injury in thirteen patients $(5.5 \%)$, and assault in thirteen patients $(5.5 \%)$.

According to AIS, the frequency of the injury sites were; thoracic, abdominal, pelvic and extremity, head and neck, maxil-

Table I. Distribution of injury sites based on AIS

\begin{tabular}{lcc}
\hline Injury site & $\mathbf{n}$ & $\%$ \\
\hline Thoracic & 131 & 55.3 \\
Abdominal & 110 & 46.4 \\
Pelvic and limb & 96 & 40.5 \\
Head and neck & 34 & 14.3 \\
Maxillofacial & 26 & 11.0 \\
External & 24 & 10.1 \\
\hline
\end{tabular}

AIS: Abbreviated injury scale.

Table 2. Distribution of trunk injuries

\begin{tabular}{lcc}
\hline Injury site & $\mathbf{n}$ & $\%$ \\
\hline Isolated & & \\
$\quad$ Thoracic & 55 & 23.2 \\
Abdominal & 42 & 17.7 \\
Pelvic & 15 & 6.3 \\
Multiple & & \\
Thoracoabdominal & 48 & 20.3 \\
Thoracoabdominopelvic & 16 & 6.8 \\
Thoracopelvic & 12 & 5.1 \\
Abdominopelvic & 4 & 1.7 \\
\hline
\end{tabular}


lofacial and external body injuries, respectively. A total of 421 injury sites (mean I.8 per patient) were identified (Table I).

When the patients were considered according to trunk injuries, thoracic, thoracoabdominal and abdominal injuries were found to be the most common. Thoracoabdominopelvic, pelvic and abdominopelvic injuries followed them (Table 2).

FAST was performed in one hundred and two of the patients, of whom seventy-threewere FAST $(+)$ and nineteen were FAST (-). When they were compared according to their FAST results, there was no significance between their mean RTS and ISS values. However, the need for transfusion and mortality rates were significantly higher in the FAST $(+)$ group (Table 3$)$.

FAST $(+)$ and hemodynamically instable twenty-five patients underwent laparotomy. In hemodynamically stable patients, FAST, CT and/or other imaging modalities were performed.
All patients were evaluated with a multidisciplinary approach. Eight of these were operated on due to unsustainable hemodynamic stability in their follow up. A total of forty-five patients (19\%) including 33 patients with hemodynamic instability and 12 patients with peritonitis-related signs were operated on. In patients operated due to hemodynamic instability, mean ISS, need for transfusion and mortality rate were significantly higher, mean RTS level was significantly lower (Table 4).

Splenectomy was performed in sixteen patients, and nephrectomy in three. Furthermore, treatments for intestinal injury in eight patients, pancreatic injury in three, and diaphragmatic injury in two were carried out. Negative laparotomy results were established in two patients with peritonitis-related signs. Two patients underwent thoracotomy due to major thoracic injury.

Hepatic packing was performed in seven patients with high-

Table 3. A statistical comparison of ISS, RTS, need for transfusion and mortality rates among FAST positive and FAST negative patients

\begin{tabular}{|c|c|c|c|}
\hline Variables & $\begin{array}{c}\text { FAST (+) } \\
(n=73)\end{array}$ & $\begin{array}{c}\text { FAST (-) } \\
(n=29)\end{array}$ & $\begin{array}{c}\text { Significance } \\
(p<0.05)\end{array}$ \\
\hline Injury Severity Scores (Mean $\pm S D)$ & $19.8 \pm 15.7$ & $17.0 \pm 12.3$ & $p=0.881$ \\
\hline Revised Trauma Scores (Mean \pm SD) & $6.99 \pm 1.95$ & $7.55 \pm 1.06$ & $p=0.160$ \\
\hline Transfusion (Mean \pm SD) & $2.4 \cup . \pm 3.2$ & $1.2 \cup . \pm 3.8$ & $p=0.004$ \\
\hline Mortality, n (\%) & $15(20.5)$ & I (3.4) & $p=0.036$ \\
\hline
\end{tabular}

FAST: Focused Assessment with Sonography in Trauma.

Table 4. A statistical comparison of ISS, RTS, need for transfusion and mortality rates among patients operated with hemodynamic unstability and stability

\begin{tabular}{|c|c|c|c|}
\hline Variables & $\begin{array}{l}\text { Hemodynamic } \\
\text { unstable }(n=33)\end{array}$ & $\begin{array}{l}\text { Hemodynamic } \\
\text { stable }(n=12)\end{array}$ & $\begin{array}{c}\text { Significance } \\
(p<0.05)\end{array}$ \\
\hline Injury Severity Scores (Mean \pm SD) & $38.6 \pm 13.4$ & $16.6 \pm 9.8$ & $\mathrm{P}=0.001$ \\
\hline Revised Trauma Scores (Mean \pm SD) & $5.25 \pm 2.45$ & $7.40 \pm 1.30$ & $\mathrm{P}=0.005$ \\
\hline Transfusion (Mean $\pm \mathrm{SD}$ ) & $7.2 \cup . \pm 3.9$ & $0.3 \cup . \pm 0.8$ & $p=0.001$ \\
\hline Mortality, n (\%) & $20(60.6 \%)$ & I (8.3\%) & $p=0.006$ \\
\hline
\end{tabular}

Table 5. A statistical comparison of ISS, RTS, need for transfusion and mortality rates among patients treated with packing versus no packing performed

\begin{tabular}{|c|c|c|c|}
\hline Variables & $\begin{array}{l}\text { Packing } \\
(n=12)\end{array}$ & $\begin{array}{c}\text { No packing } \\
(n=33)\end{array}$ & $\begin{array}{c}\text { Significance } \\
(p<0.05)\end{array}$ \\
\hline Injury Severity Scores (Mean \pm SD) & $45.1 \pm 12.1$ & $28.3 \pm 14.7$ & $p=0.001$ \\
\hline Revised Trauma Scores (Mean \pm SD) & $4.35 \pm 2.41$ & $6.35 \pm 2.18$ & $\mathrm{P}=0.012$ \\
\hline Transfusion (Mean $\pm S D$ ) & $8.4 \cup . \pm 3.1$ & $4.3 \cup . \pm 4.6$ & $p=0.003$ \\
\hline Mortality (n, \%) & $9(75 \%)$ & II (33.3\%) & $p=0.032$ \\
\hline
\end{tabular}


Table 6. Distribution of abdominal injuries and rate of nonoperative management

\begin{tabular}{lccc}
\hline Organ injury & $\mathbf{n}$ & $\%$ & NOM rate (\%) \\
\hline Spleen & 56 & 23.6 & 71.4 \\
Liver & 34 & 14.3 & 79.4 \\
Kidney & 25 & 10.5 & 88 \\
Intestine & 8 & 3.4 & - \\
Pancreas & 7 & 3.0 & 57 \\
Great vessel & 6 & 2.5 & - \\
Diaphragm & 2 & 0.8 & - \\
\hline
\end{tabular}

NOM: Non-operative management.

grade liver injury. Five patients underwent pelvic packing with unstable pelvic fracture. When patients were compared according to need for packing; in the packing group, mean ISS, need for transfusion and mortality rate were significantly higher and mean RTS level was significantly lower (Table 5).

When the patients were classified according to abdominal organ injuries; splenic injuries were in the first place, followed by liver, kidney, intestine, pancreas, intraabdominal major vessels and the diaphragm, respectively. A total of $71.4 \%$ of the patients with spleen injuries, $79.4 \%$ with liver injuries, $88 \%$ with renal injuries, and $57 \%$ with pancreatic injuries were managed non-operatively. These patients were discharged without mortality (Table 6).

When the patients were classified according to thoracic injuries, rib fracture and pneumothorax were the most com-
Table 7. Distribution of thoracic injuries

\begin{tabular}{lcc}
\hline Thoracic injury & $\mathbf{n}$ & $\%$ \\
\hline Rib fracture & 67 & 28.3 \\
Pneumothorax & 46 & 19.4 \\
Pulmonary contusion & 32 & 13.5 \\
Hemothorax & 23 & 9.7 \\
Hemopneumothorax & 22 & 9.3 \\
Thoracic vertebral fracture & 21 & 8.9 \\
Clavicle fracture & 17 & 7.2 \\
Scapula fracture & 7 & 3.0 \\
Flail chest & 3 & 1.3 \\
Sternal fracture & 1 & 0.4 \\
\hline
\end{tabular}

mon, followed by pulmonary contusion, haemothorax, hemopneumothorax, thoracic vertebra fracture, clavicula fracture, scapula fracture, flail chest, and sternum fracture. Fifty-two patients $(21.9 \%)$ underwent tube thoracostomy and two patients $(0.8 \%)$ underwent thoracotomy (Table 7$)$.

Twenty-three of 47 patients with pelvic injuries had unstable pelvic fractures and 10 of them $(43.5 \%)$ died. Additionally, mortality was seen in twenty-six (II\%) of all patients. Nine $(34.9 \%)$ of these patients had an AIS score $>4$ along with head injury.

Mean ISS and RTS levels, and need for transfusion were 18.4, 7.30 , and $1.6 \mathrm{U}$ in all patients, respectively. These values were 33.6, 5.66, and $5.4 \mathrm{U}$ in patients that were operated on, respectively; whereas, these values were $44.6,4.22$, and $7.8 \mathrm{U}$ in exitus patients, respectively. Mean ISS and need for transfu-

Table 8. A statistical comparison of ISS, RTS, and need for transfusion among patients operated on and managed non-operatively

\begin{tabular}{|c|c|c|c|c|}
\hline \multirow[t]{2}{*}{ Variables } & \multirow{2}{*}{$\frac{\text { Total }(237)}{\text { Mean } \pm S D}$} & \multirow{2}{*}{$\frac{\text { Operated patients (45) }}{\text { Mean } \pm \text { SD }}$} & \multirow{2}{*}{$\frac{\text { Non-operated patients (192) }}{\text { Mean } \pm \text { SD }}$} & \multirow[t]{2}{*}{ Significance $(p<0.05)$} \\
\hline & & & & \\
\hline Injury Severity Scores & $18.4 \pm 13.8$ & $33.6 \pm 15.8$ & $14.9 \pm 10.5$ & $\mathrm{p}<0.00 \mathrm{I}$ \\
\hline Revised Trauma Scores & $7.30 \pm 1.49$ & $5.66 \pm 2.48$ & $7.69 \pm 0.73$ & $\mathrm{p}<0.001$ \\
\hline Transfusion & $1.6 \cup . \pm 3.2$ & $5.4 \cup . \pm 4.5$ & $0.7 \cup . \pm 2.0$ & $\mathrm{p}<0.001$ \\
\hline
\end{tabular}

Table 9. A statistical comparison of ISS, RTS, and need for transfusion among survivors and exitus patients

\begin{tabular}{|c|c|c|c|}
\hline \multirow[t]{2}{*}{ Variables } & \multirow{2}{*}{$\frac{\text { Survivors }(2 I I)}{\text { Mean } \pm S D}$} & \multirow{2}{*}{$\frac{\text { Exitus patients (26) }}{\text { Mean } \pm \text { SD }}$} & \multirow[t]{2}{*}{ Significance $(p<0.05)$} \\
\hline & & & \\
\hline Injury Severity Scores & $15.2 \pm 10.0$ & $44.6 \pm 11.6$ & $p<0.001$ \\
\hline Revised Trauma Scores & $7.68 \pm 0.75$ & $4.22 \pm 2.26$ & $\mathrm{p}<0.001$ \\
\hline Transfusion (mean+SD) & $0.8 \cup . \pm 2.0$ & $7.8 \cup . \pm 4.4$ & $p<0.001$ \\
\hline
\end{tabular}


sion were statistically significantly higher in patients that were operated on compared to those who were not operated on and exitus patients compared to survivors. Mean RTS was significantly lower in these patients. $P$ value was found to be $<0.00 \mathrm{I}$ in all three variables among the patients (Tables 8 and 9). However, there was no significant difference in age and gender among the patients $(p=0.60$ and 0.22 for age; $p=0.44$ and 0.42 for gender).

\section{DISCUSSION}

Blunt trauma injuries mainly affect young adult males. Several studies have reported that such injuries mostly occur at the age of 30 to 40 years with 60 to $80 \%$ in the male gender. $[2,3,8]$ In our study, median age was 36.9 and male gender was $78.9 \%$. The main causes of blunt trauma injuries are road traffic accidents, followed by falls from height. Similarly, $62 \%$ of the patients in our study were exposed to traffic accidents, followed by $27 \%$ who fell from height.

Blunt trauma often presents with multi-trauma involving more than one anatomical structure of the body. In most of our patients, abdominal injuries were concominant with thoracic and/or pelvic injuries. In our study, mean injury site was a 2 based on AIS classification. It is interesting that only $17.7 \%$ of the patients had an isolated abdominal injury. However, majority of the patients with abdominal trauma present with thoracic and/or pelvic injuries, ${ }^{[6-8]}$ indicating that the management of patients with blunt trauma injuries requires a multidisciplinary approach, including physicians trained in the management of trauma, as well as well-equipped trauma centers. The mortality rate has been reported to be lower in healthcare centers where trauma management is satisfactory. ${ }^{[3,6,7]}$

FAST was first described by Rozycki and friends in 1996 and has an important role in the diagnoses of trauma patients in the ER. ${ }^{9,10]}$ FAST, which is rapid, easy to perform, cheap, and repeatable, can be performed in hemodynamically stable and unstable patients. ${ }^{[10]}$ However, CT is recommended only for hemodynamically stable patients. FAST positivity in unstable patients is a precise indication of laparotomy. ${ }^{[1]}$ In different studies, sensitivity of FAST ranges between $80 \%$ and $100 \%$. $[9,11,12]$ In our study, all of the hemodynamically unstable and FAST (+) twenty-five patients had several injuries in laparotomy; twenty-three (92\%) had intraabdominal organ injuries and two $(8 \%)$ had retroperitoneal and pelvic hematoma.

With respect to abdominal trauma, the most affected organs are the spleen, liver, kidney, intestines, and pancreas. ${ }^{[13]}$ The majority of solid organ injuries are followed non-operatively. [13-15] In several studies, 70-80\% non-operative management rates have beenreported for intraabdominal solid organ injuries. $^{[14-16]}$ Similarly, 7I.4\% of spleen injuries, $79.4 \%$ of liver injuries, and $88 \%$ of renal injuries were managed non-operatively in the present study.
Surgery is usually indicated in the presence of hemodynamic instability due to high-grade solid organ injuries and concomitant additional injuries. ${ }^{[15]}$ In our study, in patients operated with hemodynamic instability mortality rate, ISS level and need for transfusion were significantly higher. In particular, grade IV-V liver injury and intraabdominal great vessel injury increase the mortality rate. In different studies with high grade liver injuries and unstable pelvis fractures, 40-70\% mortality rates have been reported after packing and angioembolisation..$^{[7,16-18]}$ In our study, a total of nine patients (75\%) died including five out of 7 patients with hepatic packing and four out of 5 patients with pelvic packing.

Most hollow organ injuries can be diagnosed with clinical signs of peritonitis during follow-up and can be surgically treated. ${ }^{[15]}$ In patients with a suspicion of hollow viscus injury, CT and diagnostic laparoscopy can be used for diagnosis. ${ }^{[19,20]}$ In our study, we operated on five of eight patients with intestinal injury due to peritonitis-related signs, as revealed by repeated physical examination sessions. Diagnostic laparoscopy was performed to one of these patients. Three of the remaining patients were operated on due to haemodynamic instability caused by accompained organ injury.

Blunt trauma-induced isolated or concomitant thoracic injury is common. ${ }^{[21,22]} \mathrm{Hemo/pneumothorax} \mathrm{presenting} \mathrm{with}$ rib fractures is the most frequently seen injury. ${ }^{[22]}$ The majority of these patients are treated with tube thoracostomy. ${ }^{[21,22]}$ Unlike penetrating trauma injuries, fewer patients with blunt trauma injury require thoracotomy. ${ }^{[22]}$ In the present study, tube thoracostomy was essential and adequate in $21.9 \%$ of the patients, while $0.8 \%$ of the patients required thoracotomy. Patients with AIS $>4$ along with severe thoracic injuries had a higher mortality risk.

Unstable pelvic fracture is a type of injury that compromises hemodynamic stability and increases the mortality rate. ${ }^{[23-25]}$ Early and adequate blood product transfusion, pelvic stabilization techniques, early diagnosis and management of additional injuries, angio-embolization, avoidance of unnecessary laparotomy, and thorough monitoring in the ICU can decrease mortality. ${ }^{[26,27]}$ Extra-peritoneal pelvic packing or internal iliac artery ligation can be an alternative to angioembolization in healthcare centers where the latter is not available. ${ }^{[28]}$ Furthermore, we performed pelvic packing in five patients in our study.

In addition, the presence of concomitant head injury increases the mortality to a large extent. However, first-line therapy should include an intervention to maintain hemodynamic stability in a patient with hemodynamic instability despite the presence of a head injury. After stabilizing the patient hemodynamically, further investigations, including cranial $\mathrm{CT}$, can be performed.

Many studies have shown that ISS and RTS are major factors 
affecting mortality. ${ }^{[29-33]}$ To the best of the knowledge of the researchers, ISS $>40$ and RTS $<4.5$ dramatically increase mortality risk. ${ }^{[31-33]}$ In the present study, mean ISS was statistically significantly higher in patients who were urgently operated on, compared to those who were not operated on, and exitus patients were compared to survivors $(p<0.00 I)$. Likewise, mean RTS was significantly lower in these patients $(p<0.00 \mathrm{I})$.

Moreover, various studies have demonstrated that an increased need for transfusion is a risk factor for mortality. ${ }^{[34]}$ In our study, mean need for transfusion was $7.8 \mathrm{U}$ in exitus patients, indicating a significantly higher value compared to survivors $(p<0.001)$.

However, there are some limitations to this study. Firstly, the study was designed as retrospective with a prospective database since prospective studies including patients with trauma injuries are unlikely to be conducted. Secondly, classification of the patients was problematic as the study included various types of injury. Therefore, further studies are required to confirm our findings.

In conclusion, blunt trauma often presents with multi-trauma involving more than one anatomical structure of the body. Thoracic, abdominal, and pelvic injuries are usually accompanied. The majority of abdominal solid organ injuries are managed non-operatively. Most thoracic injuries are treated with tube thoracostomy while thoracotomy is required in a very limited number of patients. In addition, unstable pelvic fracture is a type of injury requiring an ICU stay, which increases the mortality rate. ISS, RTS, positive FAST result, packing requirement, hemodynamic unstability and need for transfusion are statistically invaluable in identifying the mortality risk.

\section{Conflict of interest: None declared.}

\section{REFERENCES}

1. World Health Organization, Global Health Observatory Data Repository, Death Rates: WORLD By cause 2011.

2. Ball SK, Croley GG 2nd. Blunt abdominal trauma. A review of $637 \mathrm{pa}-$ tients. J Miss State Med Assoc 1996;37:465-8.

3. Di Saverio S, Gambale G, Coccolini F, Catena F, Giorgini E, Ansaloni L, et al. Changes in the outcomes of severe trauma patients from 15-year experience in a Western European trauma ICU of Emilia Romagna region (1996-2010). A population cross-sectional survey study. Langenbecks Arch Surg 2014;399:109-26. CrossRef

4. Yang J, Gao JM, Hu P, Li CH, Zhao SH, Lin X. Management of multiple trauma with mainly thoracic and abdominal injuries: a report of 1166 cases. Chin J Traumatol 2009;12:118-21.

5. Trunkey DD. Trauma. Accidental and intentional injuries account for more years of life lost in the U.S. than cancer and heart disease. Among the prescribed remedies are improved preventive efforts, speedier surgery and further research. Sci Am 1983;249:28-35. CrossRef

6. Demetriades D, Martin M, Salim A, Rhee P, Brown C, Doucet J, et al. Relationship between American College of Surgeons trauma center designation and mortality in patients with severe trauma (injury severity score >
15). J Am Coll Surg 2006;202:212-5; quiz A45.

7. Demetriades D, Martin M, Salim A, Rhee P, Brown C, Chan L. The effect of trauma center designation and trauma volume on outcome in specific severe injuries. Ann Surg 2005;242:512-9. CrossRef

8. Farrath S, Parreira JG, Perlingeiro JA, Solda SC, Assef JC. Predictors of abdominal injuries in blunt trauma. Rev Col Bras Cir 2012;39:295-301.

9. Coşkun F, Akıncı E, Ceyhan MA, Sahin Kavaklı H. Our new stethoscope in the emergency department: handheld ultrasound. Ulus Travma Acil Cerrahi Derg 2011;17:488-92. CrossRef

10. Sgourakis G, Lanitis S, Korontzi M, Kontovounisios C, Zacharioudakis $\mathrm{C}$, Armoutidis V, et al. Incidental findings in focused assessment with sonography for trauma in hemodynamically stable blunt trauma patients: speaking about cost to benefit. J Trauma 2011;71:123-7. CrossRef

11. Gaarder C, Kroepelien CF, Loekke R, Hestnes M, Dormage JB, Naess PA. Ultrasound performed by radiologists-confirming the truth about FAST in trauma. J Trauma $2009 ; 67: 323-9$. CrossRef

12. Kumar S, Kumar A, Joshi MK, Rathi V. Comparison of diagnostic peritoneal lavage and focused assessment by sonography in trauma as an adjunct to primary survey in torso trauma: a prospective randomized clinical trial. Ulus Travma Acil Cerrahi Derg 2014;20:101-6. CrossRef

13. Velmahos GC, Toutouzas KG, Radin R, Chan L, Demetriades D. Nonoperative treatment of blunt injury to solid abdominal organs: a prospective study. Arch Surg 2003;138:844-51. CrossRef

14. Yanar H, Ertekin C, Taviloglu K, Kabay B, Bakkaloglu H, Guloglu R. Nonoperative treatment of multiple intra-abdominal solid organ injury after blunt abdominal trauma. J Trauma 2008;64:943-8. CrossRef

15. D’Errico E, Goffre B, Mazza D. Blunt abdominal trauma: current management. Chir Ital 2009;61:601-6.

16. Asensio JA, Roldán G, Petrone P, Rojo E, Tillou A, Kuncir E, et al. Operative management and outcomes in 103 AAST-OIS grades IV and V complex hepatic injuries: trauma surgeons still need to operate, but angioembolization helps. J Trauma 2003;54:647-54. CrossRef

17. Hagiwara A, Murata A, Matsuda T, Matsuda H, Shimazaki S. The efficacy and limitations of transarterial embolization for severe hepatic injury. J Trauma 2002;52:1091-6. CrossRef

18. Tai DK, Li WH, Lee KY, Cheng M, Lee KB, Tang LF, et al. Retroperitoneal pelvic packing in the management of hemodynamically unstable pelvic fractures: a level I trauma center experience. J Trauma 2011;71:79-86.

19. Mitsuhide K, Junichi S, Atsushi N, Masakazu D, Shinobu H, Tomohisa E, et al. Computed tomographic scanning and selective laparoscopy in the diagnosis of blunt bowel injury: a prospective study. J Trauma 2005;58:696-703. CrossRef

20. Livingston DH, Tortella BJ, Blackwood J, Machiedo GW, Rush BF Jr. The role of laparoscopy in abdominal trauma. J Trauma 1992;33:471-5.

21. Dongel I, Coskun A, Ozbay S, Bayram M, Atli B. Management of thoracic trauma in emergency service: Analysis of 1139 cases. Pak J Med Sci 2013;29:58-63.

22. Alihodzic-Pasalic A, Grbic K, Pilav A, Hadzismailovic A, Grbic E. Initial treatment of isolated thoracic injuries. Med Arch 2013;67:107-10.

23. Demetriades D, Karaiskakis M, Toutouzas K, Alo K, Velmahos G, Chan L. Pelvic fractures: epidemiology and predictors of associated abdominal injuries and outcomes. J Am Coll Surg 2002;195:1-10. CrossRef

24. Verbeek DO, Sugrue M, Balogh Z, Cass D, Civil I, Harris I, et al. Acute management of hemodynamically unstable pelvic trauma patients: time for a change? Multicenter review of recent practice. World J Surg 2008;32:1874-82. CrossRef

25. Cordts Filho Rde M, Parreira JG, Perlingeiro JA, Soldá SC, Campos Td, Assef JC. Pelvic fractures as a marker of injury severity in trauma patients. Rev Col Bras Cir 2011;38:310-6. 
26. Biffl WL, Smith WR, Moore EE, Gonzalez RJ, Morgan SJ, Hennessey T, et al. Evolution of a multidisciplinary clinical pathway for the management of unstable patients with pelvic fractures. Ann Surg 2001;233:84350. CrossRef

27. Osborn PM, Smith WR, Moore EE, Cothren CC, Morgan SJ, Williams $\mathrm{AE}$, et al. Direct retroperitoneal pelvic packing versus pelvic angiography: A comparison of two management protocols for haemodynamically unstable pelvic fractures. Injury 2009;40:54-60. CrossRef

28. Tötterman A, Madsen JE, Skaga NO, Røise O. Extraperitoneal pelvic packing: a salvage procedure to control massive traumatic pelvic hemorrhage. J Trauma 2007;62:843-52. CrossRef

29. Bruijns SR, Guly HR, Bouamra O, Lecky F, Lee WA. The value of traditional vital signs, shock index, and age-based markers in predicting trauma mortality. J Trauma Acute Care Surg 2013;74:1432-7. CrossRef

30. Içer M, Güloğlu C, Orak M, Ustündağ M. Factors affecting mortality caused by falls from height. Ulus Travma Acil Cerrahi Derg
2013;19:529-35. CrossRef

31. Sousa AN, Paiva JA, Fonseca SA, Raposo FJ, Loureiro AM, Valente LF, et al. Trauma scores in the management of politrauma patients: which one and what for?. [Article in Portuguese] Acta Med Port 2011;24:94350. [Abstract]

32. Akhavan Akbari G, Mohammadian A. Comparison of the RTS and ISS scores on prediction of survival chances in multiple trauma patients. Acta Chir Orthop Traumatol Cech 2012;79:535-9.

33. Emircan S, Ozgüç H, Akköse Aydın S, Ozdemir F, Köksal O, Bulut M. Factors affecting mortality in patients with thorax trauma. Ulus Travma Acil Cerrahi Derg 2011;17:329-33. CrossRef

34. Hussmann B, Taeger G, Lefering R, Waydhas C, Nast-Kolb D, Ruchholtz $\mathrm{S}$, et al. Lethality and outcome in multiple injured patients after severe abdominal and pelvic trauma. Influence of preclinical volume replacement - an analysis of 604 patients from the trauma registry of the DGU. [Article in German] Unfallchirurg 2011;114:705-12. [Abstract]

\section{ORIJINAL ÇALIŞMA - ÖZET}

\section{Künt travma sonucu yaralanan hastaların çok yönlü analizi ve mortaliteye etkili faktörler Dr. Adnan Özpek, ${ }^{1}$ Dr. Metin Yücel, ${ }^{1}$ Dr. İbrahim Atak, ${ }^{1}$ Dr. Gürhan Baş, ${ }^{1}$ Dr. Orhan Alimoğlu'}

${ }^{1}$ Ümraniye Eğitim ve Araştırma Hastanesi, Genel Cerrahi Kliniği, İstanbul

${ }^{2}$ Medeniyet Üniversitesi Tıp Fakültesi, Genel Cerrahi Anabilim Dalı, İstanbul

AMAÇ: Bu çalışmada künt travmaya bağı yaralanma nedeniyle kliniğimize yatırarak tedavi ettiğimiz hastaların çok yönlü analizini ve mortaliteye etkili faktörleri belirlemeyi amaçladık.

GEREÇ VE YÖNTEM: Ocak 2009 ile Ocak 2013 tarihleri arasında, künt travmaya bağlı yaralanma nedeniyle kliniğimize yatırarak tedavi ettiğimiz 237 hasta geriye dönük olarak incelendi. Hastalar yaş, cinsiyet, travmanın şekli, yaralanma bölgeleri, Yaralanma Şiddet Skoru (ISS), Revize Edilmiş Travma Skoru (RTS), FAST sonuçları, hemodinamik durum, transfüzyon gereksinimi, uygulanan tedavi yöntemi, tedavi sonuçları ve mortalite yönünden analiz edildi.

BULGULAR: Hastaların I87'si (\%78.9) erkek, 50'si (\%2I.I) kadın, yaş ortalaması 36.9 I6.9 (3-8I yıl) idi. Hastaların I3I'inde (\%55.3) torakal, I I 0 'unda (\%46.4) abdominal, 96'sında (\%40.5) pelvis ve ekstremite, 34'ünde (\% |4.3) baş ve boyun, 26'sında (\% I I) maksillofasyal, 24'ünde (\% I0.1) ise cilt ve cilt altı yumuşak doku yaralanması mevcuttu. Hemodinamik instabilite nedeniyle 33, peritonit bulguları nedeniyle 12 hasta olmak üzere toplam 45 (\%।9) hasta ameliyat edildi. Hastaların 26’sında (\%। I) mortalite görüldü ve bunların I0'unda (\%38.5) instabil pelvis kırığı bulunmaktaydı. Packing gereken hastalarda \%75, packing gerekmeyenlerde \%33.3; hemodinamisi instabil hastalarda \%60.6, hemodinamisi stabil olanlarda \%8.3 ve FAST (+) hastalarda \%20.5, FAST (-) hastalarda \%3.4 mortalite belirlendi $(p<0.05)$. Hastaların tümünde ortalama ISS değeri I8.4, RTS değeri 7.30, transfüzyon gereksinimi I.6 Ü. olarak hesaplanırken; ölen hastalarda ise aynı sırayla 44.6, 4.22 ve 7.8 Ü. olarak hesaplandı $(p<0.05)$.

TARTIŞMA: Künt travmalar genellikle birden fazla anatomik bölgede yaralanmaya neden olmakta; torakal, abdominal ve pelvik bölge yaralanmaları sıklıkla birbirine eşlik etmektedir. Abdominal solid organ yaralanmalarını büyük kısmı nonoperatif olarak takip ve tedavi edilebilmektedir. Çalışma sonuçlarımı ISS, RTS, FAST sonucu, hemodinamik instabilite, packing ve transfüzyon gereksiniminin mortalite riskini belirlemede istatistiksel olarak değerli olduğunu göstermektedir.

Anahtar sözcükler: Künt travma; mortalite; multitravma; Revize Edilmiş Travma Skoru; transfüzyon; Yaralanma Şiddet Skoru.

Ulus Travma Acil Cerrahi Derg 20I5;2I (6):477-483 doi: 10.5505/tjtes.20I5.43077 